\title{
The XVIIth International Conference, Cairns Australia
}

\author{
B. P. Oldroyd $\cdot$ M. Beekman
}

Published online: 21 December 2014

(C) International Union for the Study of Social Insects (IUSSI) 2014

\begin{abstract}
The seventeenth International Congress of the International Union for the Study of Social Insects was held in Cairns, Australia, from 13 to 18 July 2014. The Congress was attended by 576 delegates from 38 countries. The venue for the conference was the magnificent Cairns Convention Centre, which set new standards in technical excellence for an IUSSI conference. There were 37 symposia, reflecting the diverse interests of IUSSI members. Nine distinguished scientists presented plenary talks. The Hamilton award, the Union's highest honor, was presented to Professor MaryJane West-Eberhard.
\end{abstract}

The International Union for the Study of Social Insects was founded in the early 1950s, and the inaugural conference was held in Paris in 1952. The Union meets every 4 years as an international body, with additional conferences organized nationally or regionally from time to time. The XVIIth International Conference was held in Cairns, Queensland, Australia from July 13-18 2014. In a departure from past practice, the conference was held in a convention centre rather than a university or hotel. The Cairns Convention Centre was a brilliant venue, and greatly contributed to the comfort of delegates and the technical excellence of the audio-visual facilities, but it did add significantly to the cost of registration.

The organizing committee had decided on Cairns because we wanted to ensure the weather would live up to expectations. Anywhere south of Brisbane can be iffy in winter. Unlike the previous IUSSI conference held in Australia, in

B. P. Oldroyd $(\bowtie) \cdot$ M. Beekman

Behaviour and Genetics of Social Insects Laboratory, University

of Sydney, Sydney, NSW 2006, Australia

e-mail: boldroyd@bio.usyd.edu.au
Adelaide, which was held in the Australian summer in January, we anticipated that July would be more convenient for those coming from Europe and the US.

The program comprised 400 15-min oral presentations, 18 rapid-fire presentations, and 178 posters held over three poster sessions. Oral presentations and posters were gathered into 37 symposia. Each symposium was proposed and organized by 2-3 volunteers who were responsible for both selecting the speakers and chairing their session. Symposia were themselves selected after international peer review of proposed topics.

The XVIIth Congress saw a change to a more on-line style of conference. For the first time at an IUSSI conference, there was no printed book of abstracts. Instead, the program and abstracts are available permanently on line at: http:// ses.library.usyd.edu.au/handle/2123/10541. Most delegates found this arrangement very satisfactory. Foregoing a paperbased proceeding has significant cost savings and environmental benefits. Abstracts were easily accessed via wi-fi during the conference, and the permanent repository will give more exposure to our work, especially to those members who were unable to attend the conference. In writing this, we are acutely aware of how dated this paragraph will appear, even by the next conference!

\section{Plenary speakers}

Plenary speakers were nominated by IUSSI Sections. The Committee then selected nine plenary speakers, being mindful of gender, taxon and geographical balance. Researchers that had previously presented a plenary talk at an IUSSI conference were excluded. Because the European IUSSI meeting held in Tuscany in 2012 had invited only female plenary speakers, quite a few potential speakers had to be excluded. 
Ryszard Maleszka, Australian National University, Canberra

Ryszard has been leading the field of honey bee (and indeed social insect) epigenomics for some years. Epigenetic modifications to DNA, particularly, methylation of cysteine residues, can alter gene expression and the way in which genes are spliced. Ryszard reviewed progress on the role of epigenetics in queen/worker dimorphism, the regulation of worker behavior and memory formation.

\section{Alison Mercer, University of Otago, Dunedin}

Social insect workers spend their lives surrounded by chemical signals produced by the queen and other workers. Alison's group has shown how queen honey bee queen pheromones influence the ways in which workers can learn, and in particular, how the presence of queen pheromone increases the ability of workers to learn to associate an adverse stimulus with an odor. Alyson pointed out that a component of the honey bee Queen Mandibular Pheromone is structurally similar to dopamine, suggesting that queen pheromone acts directly on the brains of workers to modulate their behavior.

\section{Amy Toth, Iowa State University, Ames}

Amy's work is currently focused on comparative genomics of primitively eusocial wasps and highly eusocial bees. Her work is revealing the gene networks that are causally associated with division of labor and reproductive skew in paper wasps. A particular focus is the question of whether novel genes are required for eusociality, or if eusociality can arise by modification of existing gene networks.

\section{Jae Chun Choe, National Institute of Ecology, Seocheon}

Well known for his entertaining books on ants and evolution, Jae is founding Director of South Korea's new National Institute of Ecology. Jae spoke on the difficulties of establishing the discipline of ecology in Korea, and how these difficulties have been overcome. He also spoke on his work on selfish genetic elements in the thlytokous ant Vollenhovia emery.

Judith Korb, University of Freiburg, Freiburg

Least, we forgot that there are social insects outside the Hymenoptera, Judith filled us in on the latest in the social organization of termites, focusing on Cryptotermes secundus (appropriately) an Australian species of dry wood termite, whose small colonies are particularly amenable to experimentation. Judith discussed her work on identifying the genes that regulate developmental plasticity and the queen caste.

Martin Giurfa, University of Toulouse, Toulouse

The brain of a honey bee can rest comfortably on the head of a pin. Despite this diminutive size, Martin revealed some of the astounding cognitive feats that bees are capable of, including non-elemental pattern discrimination, the ability to learn concepts such as 'sameness' and 'difference' and the to ability to generalize.

Kazuki Tsuji, University of the Ryukyus, Nishihara

Being clonal has its advantages. For one thing it eliminates within-colony genetic variance, so that there is no incentive for workers to cheat and become reproductive. However, Kazuki has been studying the societies of the clonal parthenogenetic ant Pristomyrmex punctatus, and has revealed a parasitic 'cheater' lineage has been parasitising the cooperative population for 8,000 years. The parasitism is maintained by the twin evolutionary forces of individual selection for cheating, and colony-level selection to detect and root out the cheaters.

Jay Evans, USDA Bee Research Laboratory, Beltsville

Few of us would be unaware of media stories about honey bee Colony Collapse Disorder. Jay is at the forefront of understanding the biotic and abiotic factors that underlie Colony Collapse, often based on genomic approaches. There was considerable media interest in Jay's talk.

Justin O'Riain, University of Cape Town, Capetown

It is always good to learn what's going on in social behavior research outside social insects. In a provocative talk, Justin critically examined the data on eusociality in mole rats, concluding that claims of morphological differentiation between queens and workers are not always justified.

\section{Hamilton award}

The Hamilton award was established in 2006 to recognize the seminal contributions of Bill Hamilton to the field of sociobiology. The award is made at each International Congress to recognize lifetime achievements in social insect research. Past recipients were Ross Crozier (2006) and Charles Michener (2010). The 2014 award was presented to Professor Mary Jane West-Eberhard in recognition of her outstanding contributions to the understanding of the evolution of social wasps, and her contributions to biology more 
broadly-particularly, to the concept of phenotypic plasticity.

Student awards

There were four awards for the best student posters:

Timothée Brütsch, University of Lausanne, Switzerland 'The mechanisms of resin use in wood ants'; Rafael Barbieri, Victoria University, New Zealand 'Pesticide changes odds of interactions between native and invasive ants'; Natália de Souza Araujo, University of São Paulo, Brazil, Transcriptome assembly for non-model Apinae bees: reference or de novo approach?'; Christian Pinkalski, Aarhus University, Denmark 'Non-destructive estimation of Oecophylla smaragdina colony biomass'. Acknowledging how difficult it had been to pick winners from the outstanding selection, the judges made honorable mentions of the posters of: Nurdyana Abdul Rahman, Queensland Brain Institute, Australia; Madlen Kratze, University of Western Australia, Australia; Monika Marxer, ETH Zurich, Switzerland and Kevin Loope, Cornell University, USA. Congratulations to all the winners and runners up for their outstanding work.

The student prizes were sponsored by the Wheen Bee foundation. The foundation was established as a bequest of Gretchen Wheen a famous Australian queen breeder who had a deep interest in scientific breeding.

Our thanks to the judges, Drs. Nadine Chapman, Simon Tierney, Theo Evans and Davide Santoro for performing this difficult and time consuming task so well.

\section{Beekeeper outreach}

Much social insect research is applied, and much of the applied work is on honey bees. A satellite meeting for beekeepers was held immediately after the conference, which featured some of the top honey bee researchers attending the conference. Local beekeepers benefitted strongly from the satellite workshop. Plenary speaker Jay Evans also addressed the Victorian Apiarist's Association Conference before the Cairns meeting. The Congress organizers gratefully acknowledge the sponsorship of Jay's Plenary by the honey bee program of the Rural Industries Research and Development Corporation.

\section{Stingless bee tour}

Tropical Queensland is a bit of a paradise for social insect researchers, and it was not unusual to spot a delegate down on his/her knees in a park, admiring some of the local fauna. Many delegates organized their own field trips into the Daintree Rainforest and beyond. Local stingless bee expert Tim Heard organized a bus load of delegates to visit Wendy Forno's stingless bee apiaries. Many thanks to both Wendy and Tim.

\section{Next conference}

Klaus Hartfelder from the University of São Paulo was elected president of the Union for the next 4 years. Klaus will be responsible for organizing the next international conference to be held at the beach city of Guarujá, Brazil in the week of August 5-10, 2018. The Union gratefully acknowledges the alternative offer to host the conference in Phoenix. Thank you Jen Fewell and team.

\section{Election of office bearers}

The Secretary General Joan Herbers, and the Editor-inChief of Insectes Sociaux Johan Billen resigned their positions after many years of service. The Union greatly appreciates the enormous contribution of Johan and Joan for their respective roles in the Union's affairs. Most IUSSI members will associate Johan with Insectes Sociaux, which is not surprising as he has been leading the journal for over 20 years. Under Johan's editorship Insectes Sociaux has grown in size and frequency, and remains the premier outlet for social insect research. Joan steered the Union to greater financial stability, and introduced governance and financial procedures that will greatly facilitate the efficient running of the Union and provide a more transparent decision-making process.

Michael Breed from Colorado State University was elected as the new Editor-in-Chief of Insectes Sociaux and Madeleine Beekman, University of Sydney as the new Secretary General. Congratulations to both.

\section{Thank you!}

We thank the members of the organizing committee for their help in arranging this most successful conference: Simon Robson and Lori Larch, James Cook University and Judith Reinhard from the University of Queensland. We also thank our professional event organizers, ICMS Australia, particularly, Emma Boyer, Jodie Doyle and Anne Binegas-Small. Thank you, we could not have done it without you.

Finally, we thank the conference sponsors who have not yet been mentioned: Springer, publisher of Insectes Sociaux, The School of Biological Sciences, University of Sydney, the Center for Tropical Biodiversity and Climate Change, James Cook University, The Entomological Society of America, the Cairns Convention Centre who provided a useful discount and the Queensland Government for a conference development grant. 